T. N. Mikayılov ${ }^{1}$, A. A. Bayramov ${ }^{2,3}$

${ }^{1}$ Ministry of Defence of the Azerbaijan Republic, Baku, Azerbaijan

${ }^{2}$ War College of Armed Forces of the Azerbaijan Republic, Baku, Azerbaijan

${ }^{3}$ Control Systems Institute of the Azerbaijan National Academy of Sciences, Baku, Azerbaijan

\title{
PRINCIPLES OF USING THE MATHEMATICAL MODELS OF COMBAT ACTIVITIES AND MEANS OF DESTRUCTIONS DURING OPERATIONAL PREPARATION OF THE TROOPS
}

\begin{abstract}
Development of information and computer technology requires a qualitatively new approach to the application of mathematical modeling of combat activities and activities of guns damage in planning proccesses. The article describes the history of mathematical models of combat activities and combat means of destructions, and their development paths of the use of troops in process of preparation of the operational activities. The possibilities of using mathematical models of operations (combat and fire destruction) in process of the preparation and conduct of operational preparations were considered. The urgency of the issue in this case is determined by the increased intensity of researches and supply of armed forces with information technology carried out in different countries. The analysis shows that it is necessary to use mathematical programming to predict the operations by comander and command and control staff during operational preparation.
\end{abstract}

Keywords : mathematical model; combat activities; destruction by combat means; activity of operational preparations; modeling of management.

\section{Introduction}

One of the main mechanisms for the preparation and implementation of decision-making process and implementation of combat operations and destruction activities, as well as assignments to troops (forces) is applying of the computer information technologies, including geographical and video information technologies, mathematical models, information, information computing and computing complex application of issues. These are the main principles of automation of the troops (forces) and management of guns damage processes. These are gives much more opportunities to the commander of the troops and staffs of the command and control center of troops to continuously getting an information, analyzing it, evaluating the situation and making decision.

Development of information and computer technology requires a qualitatively new approach to the application of mathematical modeling of combat activities and activities of guns damage in planning proccesses. The practice of applying mathematical models and information as well as data computing issues in the process of operational preparations determines the needs to clarify specific software requirements. The dynamic development of computing techniques, proqramming and telecommunication technologies makes a strong leap in he field of creating operational modeling systems, and gives an opportunity to simulating combat operations in the process of operational preparation of troops and activities of firearms damage by computerized mathematical model [1]. So, the effectiveness of planning and management of combat operations is enhanced by improvement and implementation of mathematical modeling.

The urgency of the issue in this case is determined by the increased intensity of researches and supply of armed forces with information technology carried out in different countries [2].The analysis shows that it is necessary to use mathematical programming to predict the operations by comander and command and control staff during operational preparation.

\section{Justification of the application of the mathematical modeling of combat}

According with the instructions the main functions of the command and control posts are data collection, assessment, forecasting real condition and planning of operations. It is well known that the planning should be fairly clear, and here, mainly to intend the solution of computational issues. Miscelaneous mathematical prediction methods for assessment of the combat condition, prediction its changes, comparative methods of rating planned activity of troops and its use are required.

The development of the methods of mathematical modeling of martial arts and firearms damage is the nessessity of resolving the constant contradiction between the two contradictory tendencies [3]. This is to increasing the accuracy of the predicted results and to reduce the modeling time.

This contradictions is due to the fact that the time of modeling according to the necessity of increasing the number of factors that are modeled for increasing the accuracy of the prediction and the number of factors to be taken into account. There are always research for the way to improve the relevance and efficiency of the problem during the modeling.

During operational preparations, for a more detailed assessment of the impact of contradiction to the nature of application models their division into the next stages can be nated:

- preparation of operational activity;

- carrying out operational activity;

- analysis of the results of operational activitycarried out.

Depending on use purpose, it can be HQ and research operational madels.As a rule, they are differ 
according to the used mathematical modeling apparatus, the degree of detailing and the number of factors that are taken into consideration.

Because of the form of description of the mutual contingency process of the parties involved in the conflict, mathematical models are divided into analytic and research [1].

HQ models typically use analytical imitation modeling, research model use random imitation modeling.

It is imperative to achieve a reduction in the time of modeling, while maintaining the integrity of the results, in the course of operational precautionary measures, when it is time-consuming for mentally computing. For this reason, the use of headquarters models is more important $[4,5]$.

HQ models include mathematical models of operations designed to provide practical operation activity of command and control posts. There are two basic requirements:

- the ability to apply a real-time operation in accordance with the operational algorithm in the decision-making process;

- ensuring objectivity and justification of decisions taken to command and control of troops (forces) on the basis of comparison of the results of the alternative variants.

From the latter requirement seems that the headquarters model should have a comparative feature of the different decision options. Necessary conditions for this are the duplication of predictive results with the starup data in the same database.

Random models can not provide this, except when the middleware results of the some models are handled by same way. This approach in the real is not practically used by headquarters.

From the scientific research experience of mathematical models in many countries, it can be seen that more detailed research models may be used when there is sufficient time to conduct and analyze operational preparations.

The practical application of random models is not used because the comparison of the result of the decision its repeatability is very complicated.

It is therefore more appropriate to use analytical headquarters models that use legitimate methods of imitation modeling of combat and fire-damage activities during operational preparations $[4,5]$.

In some cases, the following factors should be clarified in terms of the correct understanding of the matter:

- adoption of the mathematical modeling termonology;

- classification of mathematical models and prediction methods:

- use and realize technology of contemporary mathematical models;

- basic methods and fields of application of mathematical models.

It identifies the mathematical model and computational issues of the automated control system of troops, mathematical and software applications.
The mathematical model of the operation (combat activity and firearms damage) - is a mathematical mindset and mentality system that allows the compiler to calculate the basic elements of the warfare models modeled in time and to calculate the edict value of the predictions and outcomes of the predicted combat phenomena $[6,7]$.

The computational issue - is the result of mathematical dependences, algorithms and data for operational tactical (operational - strategic) or special calculations, which require the assessment of the conditions that might arise as a result of the intended activities $[7,8]$.

For computational issues, as a rule, it is sufficient to use the appropriate dependencies wthout taking immediate time and spatial structure to the process considered. Mathematical models are not created without the imitation structure of the modeled action, with no time and space indices. In this sense, mathematical models are practically always imitated. Thus, simplification may be due to the nature of prediction methods used in calculating issues, headquaters and research models:

- computational issues use an analytical framework that directly describes the impact of the starting point on the outcome of the calculations;

- the headquarters models are generally based on the specific methods of imitation models;

- research models typically use random methods of imitation modeling.

In their function, models are divided into two groups: those are directly (descriptive) and optimistic. The first ones answer the questions "what will happen in this case," and the second one "for this case what need to do". The more illustrative models are applied in the militiary issue.

The application of perspective models prevents the complexity of the issues created to find the optimal solution of a large number of factors. Also, it is becoming hard to use the obtained results.

Here, the model should be understood as a support link of one the steps of a mechanism for the assessment of quality of taken decisions, but not as a direct order to use of troops.

Models can be used:

- directly composition of the specific proggram software of automated command and control systems of troops (ACCST);

- composition of Fixed and mobile special designed modeling centers (computerized combat activities and filling firefighting computer centers).

Headquarters mathematical models that provide functionality within ACCST specific software should provide automated information exchange with other systems and data bases of this system. The management interface of modeling prosess should allow to effectively use staff models for officers of comand and control staff

Different and sophisticated models depending on their functionality,can be used in a spesific computer modeling center, not incluted in the ACCST specific program content. This is due to the folowing factors: 
- more skilled professionals are required to handle complex models;

- complicated models, complexes and systems can form more tecnical requirements than the opportunity of resources of ACCST.

Computer centers of modeling of combat activity and firearms damage proccess being stasionar and mobile can be equipped with a variety of compact computers. However, in this case, the terms of information compatibility between the computer center and ACCST must be observed.

\section{Establishing headquarters models of combat activities and firearms damage}

In recent years, great experince has been gained in the way to creating research models of Army operations. Gradually, this model has been upgraded and used in integrated and modern information technology to create a variety of militiary modeifications of combant activities of troops and firearms damage operation. Scientists from the leading countries are working on updating the software, taking into account the experience of the latest armed conflict.

These models are activale used in managment during operational preparations. It has been discovered that that they have been over-sized and have been devoting much time to the initialization of the modeling. In this case, it seems to be necessary to develop more updated mathematical models that can be used directly in the preparation of operational preparations, teamwork and training exercises, as well as inthe course of combat operations. Unlike research models, the development of the new models involved the creation of a mathematical apparatus of the model, the organization of data preparation, its incorporation into the system and the modification of the models.

The first deployed military operations headquartes model had many advantages, allowing 15 days of the militiary operation to be counted for 40 minutes by computer technology.

The wide-range experience practice of this model in operational preparations has allowed it to plan further improvements and to inentify tasks for creating new versions of the militiary operation model.

Further, improving the exchange of information among users of the model enabled the officials to directly control the process of modeling, adjust the decision-making process, divide the forces and tools during the operation ,and re-group the second echelons and resources.

The model of the army operation is designed to predict the outcome of combat operations, as well as the options for effective use of forces and means of their troops during the preparation and conduct of the operation [1]. The Commander and his staff are able to draw conclusions from the main elements of the decision by analyzing and summarizing the modeling outcomes, the intent of the operation, the content of the tasks assigned to the troops, and the key questions of the interaction.
The army Operation Model is widely used in command and staff exercises and exercises, practically used in the headquarters of all troops (military) as well as in ilitary training and research institutions. Then the gained experience is used to creaty new headquarters model and issues.

Currently, information technology, reflective means, geoinformation systems and information base are developing at high tempo. All of them contribute to the creation and development of the new ACCST [6]. In such circumstances, the reserch team is instructed to create a model of combat operations and firearms damage activity models in the development of these technologies. Developed mathematical models are used in the ACCST special safeguard software for general operations. It is tendency that defines the characteristics of the application of combat operations and mathematical models of fire-fighting in operational preparations.

\section{Fighting activities and fire-extinguishing models application in operational preparations}

In the modern era, the basic methodological principles of preparation and implementation of operational preparations of many countries are determined and information (computer) technologies are applied in the headquarters' activities in a complex form. As a rule, the use of the operation (combat operations and fire-fighting) models and other computational components in these activities is carried out by specially designated officers in the headquarters. This is due to the constant increase in the requirements for the specialization of officials in the governing bodies and the continuous improvement of the modifications of the modules.

Prepare a pre-trainee training program with the use of a generic operation model in operational preparations. During this period, the IT officers have been trained to work with the software makers in their respective headquarters. Such training is repeated every time before the training. In team headquarters games or exercises, the mathematical modeling team is codified in the governing points [6]. Also, the trained administrators are assigned specifically assigned specialists for methodological support for operationaltactical calculations and mathematical modeling.

In the course of operational preparations, the use of mathematical models and information-calculation issues is based on the indicators of combat capability, the strength and the means of fighting, the intent and the modeling of the decision in the headquarters games or events [8].

Calculation and modeling results of combat activities are submitted to the headquarters for analysis of the training.

Considering the development of information technology and the provision of technical means, the computing-modeling complex that functions in a single database and navigation system can be in the next form.

The means of planning and decision-making are: 
- mathematical model of air operations;

- calculation and modeling complex to ensure overall planning of firearms in the operation;

- mathematical model of the general operation;

- the calculation of the strengths and resources of the parties, operational and tactical intensity;

- complex of information-calculation issues on calculation of the time of preparation of the operation.

Reorganization planning tools:

- complex of information and computing issues to ensure strategic and operational resettlement of troops (forces);

- calculation of anchor (junction) anchor;

- a set of information computing issues to ensure the planning of transportation of troops (vehicles) by different means of transport.

Information support means:

- a specialized database and its means of communication;

- system of mapping and handling of the electron map of the area.

Just the practice of applying mathematical models and information-computing issues will allow them to form realistic requirements after training, make necessary corrections, and use them in the next operational preparations [9].

The development of mathematical models of combat activities and fire-fired illnesses will allow the use of the next technologies consistently through their application in operational preparation requirements:

- modeling of combat activities and fire damage in a rectangular coordinate system on a topographic map background;

- automatic mapping of the characteristics of the area in map mappings with geoinformational systems;

- choosing a more efficient version of simultaneous operation with several modeling options and application of their own troops;

- Integration of model database with different databases;

- information support within the computationalmodeling complex of various models;

- forming a modeling model for the start-up of the data acquired from the previous stage for internal control by the operator;

- application of the model of co-ordination of the parties involved and the distribution of databases.

The mathematical models of operations have become a mechanism that allows the selection of a scientifically justified effective version of the application, in accordance with the operating conditions and the assigned task, forces and means in limited time.

The results of the modeling meet the criteria for selective evaluation of combat activities and the effectiveness of firearms. In this case, the considered option is the basis of the intent of the upcoming operation, and its separate elements can be considered as the basis of the contents of the tasks for the troops.

With the development of the GIS, various software tools have been deployed to workplace headquarters. Collection of condition information, implementation of video conferencing, etc. at the same time with questions, constitutes the computational-analytical activity of the key roles of the managers.

However, despite the successful implementation of the model in the headquarters, stationary computers are located in computing centers and are far from operative management. Since direct users of the model are officers of the computing center, their assignment from the operating staff reduces the effectiveness of the model in the headquarters operation.

The following are the main reasons for this:

- lack of experience in the design and use of models of officials involved in computational and analytical activities in the military administration;

- spend a lot of time in the execution of proposals and suggestions from the governing bodies, because large-scale and very labor-intensive work is being done.

Mathematical models can be adapted directly to the user's needs, with a systematic approach to the development of the models.

At present, the model of the application of the other types of troops in the leading scientific research institutions is developed and developed [10]. This is a modular unit that combines the types of troops based on the general operation model. New computing modules are being developed that allow you to improve the accuracy of modeling processes.

Along with the questions of the model of the general operation model for the new programming, the work is carried out in the following directions:

- development of the scenario interactive editor (model management tools - the main module that coordinates the sequence of the components of the model) in accordance with operational tasks;

- development of appropriate modules for harmonization of types of troops between time and events;

- creation of database model and its integration into database of other calculation and modeling tools.

The model of the other type of force (type of force) is developed as a universal governance system that enables modeling of non-contact combat activities and fires, as well as modeling classic peer-to-peer operations.

\section{Conclusions}

Mathematical modeling of combat operations and firearms in the general operations, its development and use remains relevant. It is expedient that it is necessary to ensure the continuity and scientific accompaniment of the establishment process:

1. Particular attention should be paid to the development of mathematical modeling in the field of Western science and training of military-scientific personnel;

2. In addition to good programmers, mathematicians and analysts, specializing practitioners should be involved in the design and implementation of models for combat activities and fire-fighting;

3. Ensure close interaction between the Western science and experts in the field of science on continuing work on the creation and development of armed conflicts models. 


\section{REFERENCES}

1. Mikayllov, T.N. and Bayramov, A.A. (2018), "Modelling of the assessment of fire destruction of objects", Herbi bilik, Baku, No. 5, pp. 3-12.

2. Vrakopulo, V.N. (2003), "The possibilities of application of the combat modelling during computer military games", Proc. of the Scientific Workshop "State of art and the development of military combat activities", Minsk, pp. 62- 67.

3. Mikayilov, T.N. and Bayramov, A.A. (2019), "The possibility of creating an automated control system of various military units", Advanced Information Systems, Vol. 3, No. 3. pp. 25-29, DOI: https://doi.org/10.20998/2522-9052.2019.3.03

4. Sayfetdinov, X.I. (1998), "Reformation of combat training: computer-training forms", Voennaya Misl, Moscow, No. 4, pp. 12-16.

5. Sayfetdinov, X.I. (2004), "Computer forms of operational training: the problems of improving and ways of solution", Voennaya Misl, No. 7, pp. 2-11.

6. Mikayilov, T.N. and Bayramov, A.A. (2019), "The factors of enemy destruction fire in the single information space during combat operations", Journal of Defense Resources Management, Brasov - Romania, Vol. 10, issue 1(18), pp. 121-130.

7. Nekrashenko A.N.(2004), "Computer military game: the assessment of staff solution", Voennaya Misl, No.4, pp. 27-30.

8. Glushenko, V.V. and Glushenko, I.I. (1997), Development of management decision. Forecasting - planning. Theory of experiments planning, Krilya, Moscow, $400 \mathrm{p}$.

9. Ryabchuk, V.D. (1995), The elements of military systemology, Military Academy afte M. Frunze, Moscow, 228 p.

10. Grachev I.A. (2002), "Principles of the construction of espeial mathematical and software for ASC troops", Voennaya Misl, No. 2, pp. 12-19.

Received (надійшла) 23.12.2019

Accepted for publication (прийнята до друку) 29.01.2020

\section{ABOUT THE AUTHORS / ВіДOMOCTI ПРО АВTOPIB}

Мікаілов Телман Неман огли - доцент, полковник, Міністерство Оборони Азербайджанської Республіки, Баку, Азербайджан; Telman Neman oğlu Mikayılov - assistant-professor, colonel, Ministry of Defense of the Azerbaijan Republic, Baku, Azerbaijan; e-mail: telman.mikayilov@yahoo.com; ORCID ID: http://orcid.org/0000- 0003-2608-7813.

Байрамов Азад Агалар оглы- доктор фізико-математичних наук, професор, професор-консультант, Військова Академія Збройних Сил Азербайджанської Республіки, Баку, Азербайджан;

Azad Agalar oğlu Bayramov - Doctor of Physics and Mathematics, Professor, National War College of Armed Forces of the Azerbaijan Republic; Control Systems Institute of the Azerbaijan National Academy of Sciences Baku, Azerbaijan; e-mail: azad.bayramov@yahoo.com; ORCID ID: https://orcid.org/0000-0001-6672-2338.

\section{Принципи застосування математичних моделей бойових дій і вогневого ураження в оперативній підготовці військ \\ Т. Н. Микаілов, А. А. Байрамов}

Анотація. Розробка інформаційних і комп'ютерних технологій вимагає якісного нового підходу до застосування математичного моделювання бойових дій і вогневого ураження в процесах планування. У статті показані історія створення математичних моделей бойових дій і вогневого ураження і шляхи їх розвитку в результаті застосування в заходах оперативної підготовки військ. Розглянуто можливості застосування математичних моделей операцій (бойових дій і вогневого ураження) в ході підготовки і проведення заходів оперативної підготовки. Необхідність даної роботи обумовлена збільшеною інтенсивністю досліджень і застосування інформаційних технологій в збройних силах в різних країн світу. Аналіз показує, що необхідно використовувати математичне програмування для передбачення результату операцій командиром, для управління і контролю особового складу під час підготовки операцій.

Ключові слова: математична модель; бойові дії; вогневе ураження; заходи оперативної підготовки; моделювання управління.

\section{Принципы применения математических моделей боевых действий и огневого поражения в оперативной подготовке войск \\ Т. Н. Микаилов, А. А. Байрамов}

Аннотация. Разработка информационных и компьютерных технологий требует качественного нового подхода к применению математического моделирования боевых действий и огневого поражения в процессах планирования. В статье показаны история создания математических моделей боевых действий и огневого поражения и пути их развития в результате применения в мероприятиях оперативной подготовки войск. Рассмотрены возможности применения математических моделей операций (боевых действий и огневого поражения) в ходе подготовки и проведения мероприятий оперативной подготовки. Необходимость данной работы обусловлена возросшей интенсивностью исследований и применения информационных технологий в вооруженных силах в различных странах мира. Анализ показывает, что необходимо использовать математическое программирование для предсказания исхода операций командиром, для управления и контроля личного состава во время подготовки операций.

Ключевые слова: математическая модель; боевые действия; огневое поражение; мероприятия оперативной подготовки; моделирование управления. 